\title{
The contribution of particulate matter to respiratory allergy
}

\author{
Mongkhon Sompornrattanaphan, ${ }^{1}$ Torpong Thongngarm, ${ }^{1}$ Pailin Ratanawatkul, ${ }^{2}$ Chamard Wongsa, ${ }^{1}$ Jeffrey J. Swigris ${ }^{3}$
}

\begin{abstract}
Background: Air pollution contributes to an estimated six million deaths per year. Epidemiological and experimental studies show an association between air pollutant exposure and respiratory allergy.

Objective: We aimed to write a narrative review of the epidemiology of air pollution-related respiratory-related allergic disorders (including asthma and allergic rhinitis) and the effects of air pollutants - with an emphasis on the particulate matter - on respiratory allergy-related health.

Methods: PubMed Medline was searched, and representative epidemiologic and controlled-exposure studies were selected by using terms for air pollutants, particulate matter, and respiratory allergy including asthma and allergic rhinitis.

Results: Epidemiological studies showed methodologic heterogeneity, including variability in study populations, geographical regions, types and sources of pollutants, methods for exposure estimation, approaches to controlling for confounding, and case definitions. This heterogeneity affected measures of association between studies. There is strong evidence to support an association between exposure to particulate matter and asthmatic exacerbations. Although data are inconclusive, several studies suggest exposure to particulate matter contributes to the development of asthma, allergic sensitization, and allergic rhinitis. Experimental studies, such as controlled-exposure studies, support a causal association between particulate matter and adverse health effects.

Conclusions: Particulate matter exposure can exacerbate pre-existing asthma and may contribute to developing asthma, allergic rhinitis, and aeroallergen sensitization. Short-term and long-term strategies are needed to reduce disease severity and prevent new-onset disease development. Additional research is needed to identify effective avoidance strategies and therapeutic approaches.
\end{abstract}

Key words: Air pollution, particulate matter, allergy, asthma, allergic rhinitis

From:

${ }^{1}$ Division of Allergy and Clinical Immunology, Department of Medicine, Siriraj Hospital, Mahidol University, Thailand

${ }^{2}$ Division of Pulmonary and Critical Care Medicine, Faculty of Medicine, Khon Kaen University, Thailand

${ }^{3}$ Interstitial Lung Disease Program, National Jewish Health, Denver, CO, United States

\section{Corresponding author:}

Mongkhon Sompornrattanaphan

Division of Allergy and Clinical Immunology, Department of

Medicine, Faculty of Medicine, Siriraj Hospital, Mahidol University

2 Prannok Rd., Bangkok Noi, Bangkok 10700, Thailand

E-mail: mongkhon.som@mahidol.ac.th, bankallergymed@gmail.com

\section{Abbreviations}

- aOR. Adjusted odd ratio

- BAMSE, Barn Allergi Miljö Stockholm Epidemiologi

- BC, British Columbia

- CAPPS, Canadian Asthma Primary Prevention Study

- CHS, The Southern California Children's Health Study

- CHEER, Children's HEalth and Environmental Research

- CI, Confidence interval

\section{Abbreviations (Continued)}

- CO, Carbon monoxide

- COPD, Chronic obstructive pulmonary disease

- DEP, Diesel exhaust particles

- GINI, German Infant study on the influence of Nutrition Intervention

- GINIplus, German Infant study on the influence of Nutrition Intervention plus environmental and genetic influences on allergy development

- HDM, House dust mites

- IgE: Immunoglobulin E

- ISAAC, The International Study of Asthma and Allergies in Childhood

- kAU/L: Kilo allergy unit per liter

- LISA, Influence of Life style factors on the development of the Immune System and Allergies in East and West Germany

- LISAplus, Influence of Life style factors on the development of the Immune System and Allergies in East and West Germany plus the influence of traffic emissions and genetics

- MAAS, Manchester Asthma and Allergy Study

- MeDALL, Framework of the European collaborative Mechanisms of the Development of Allergy

- NOx, Oxides of nitrogen 
Abbreviations (Continued)

- $\mathrm{O}_{3}$, Ozone

- OR. Odd ratio;

- PIAMA, Prevention and incidence of asthma and mite allergy

- PM, Particulate matter

- PM10, Inhalable particulate matter

- PM10-2.5, Coarse particulate matter

- PM2.5, Fine particulate matter

- PM0.1, Ultrafine particulate matter

- Vancouver, Vancouver birth cohort

- $\mathrm{SO}_{2}$, Sulfur dioxide

- TMCHD, Taiwan Maternal and Child Health Database

- TRPA1, Transient receptor potential ankyrin-1

- VOCs, Volatile organic compounds

\section{Introduction}

Air pollution is the contamination of indoor or outdoor air by a range of substances that modify its natural characteristics. ${ }^{1}$ Increasing air pollution is associated with rapid economic growth and industrialization. ${ }^{2}$ Data from the Global Burden of Diseases 2015 study estimated that pollution contributes to nine million deaths per year, and air pollution - including ambient and indoor - was playing a role in at least six million deaths per year. ${ }^{3}$

Over the last several decades, the world has witnessed a concerning increase in the prevalence of allergic respiratory diseases. ${ }^{4,5}$ Initially observed only in industrialized Europe and North America, more recently, many other countries with rapidly-growing economies (e.g., in Asia-Pacific, such as China) have experienced a similar rise in prevalence. ${ }^{6}$ For example, previously low levels of allergy and asthma in Southeast Asia have escalated to match levels in Western countries. The causes are not fully understood but unlikely explained by genetic factors alone. Many epidemiological and experimental exposure studies suggest exposure to air pollutants is a driver. ${ }^{7,8}$ Particulate matter $(\mathrm{PM})$ with a median aerodynamic diameter $\leq 2.5$ $\mu \mathrm{m}$ (PM2.5) has garnered particular interest among stakeholders concerned with the effects of air pollution on respiratory health at the population level because of its small size and high surface area to volume ratio.

Given the growing burden of air pollution-related allergic respiratory disorders, clinicians need to be aware of the possible effects of this exposure on their patients. In this article, we discuss in detail the association between allergic respiratory disease and air pollution, with an emphasis on PM which the World Health Organization recognizes as the main air quality indicator. ${ }^{9}$

\section{Air pollutants}

Air pollutants are composed of a heterogeneous mixture of suspended gases, liquids, and solids, and they are classified according to their physicochemical properties (Figure 1). Sources of air pollution include combustion of man-made or naturally-occurring biomass or fossil fuels. Man-made sources include burning materials, industry, vehicular traffic, and environmental tobacco smoke. Naturally-occurring sources include volcanic ash, wildfires, various gases, and spontaneous secondary pollutants. Air pollutants may interact with airborne

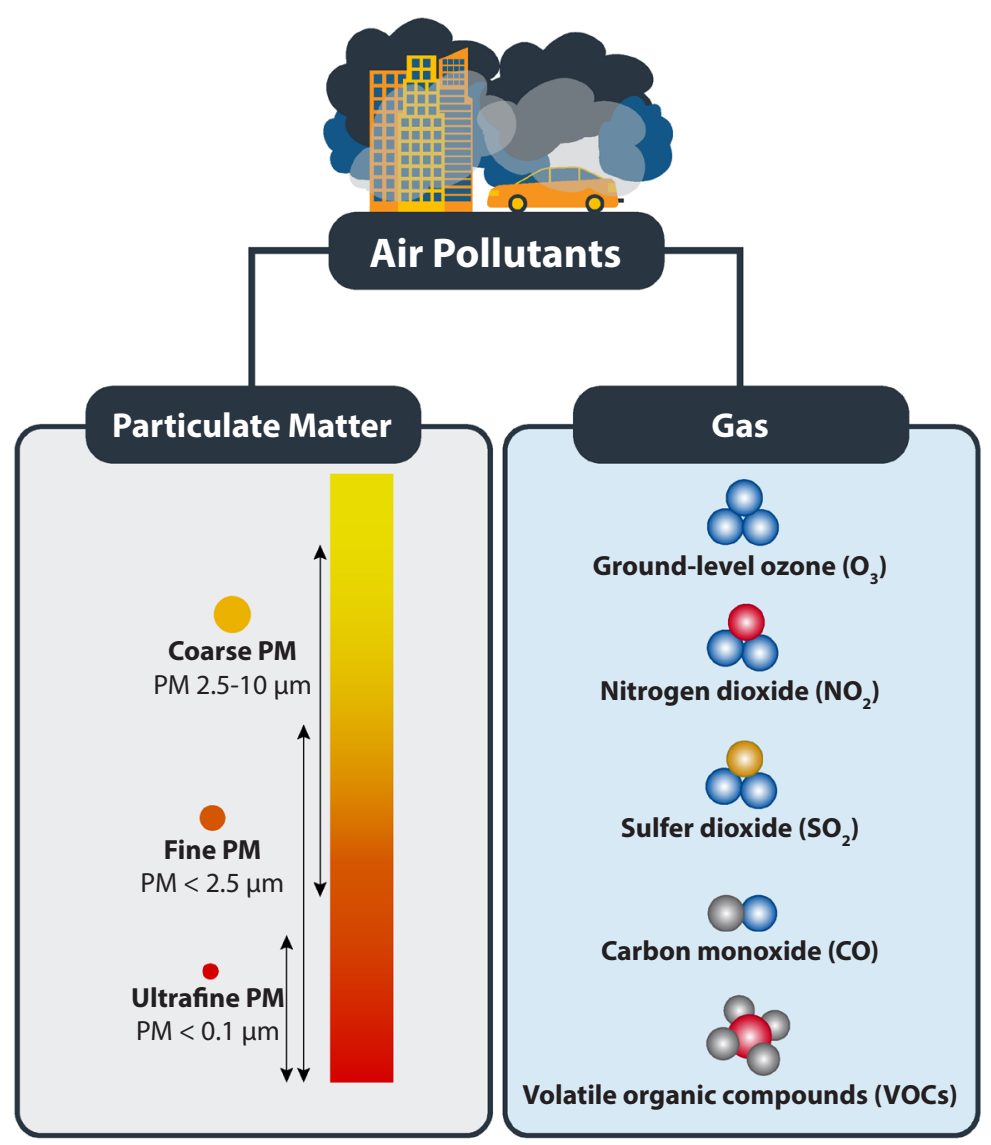

Figure 1. Classification of air pollutant according to some physical properties Abbreviation: PM, particulate matter 
allergens. In vitro and animal studies have shown that combined exposure to air pollutants and allergens may have synergistic adverse effects on allergic respiratory conditions.

\section{Particulate matter}

The airborne PM is a mixture of liquid droplets and solid particles, such as dust, dirt, soot, or smoke. Airborne PM varies in size, composition, and origin and is often classified by median aerodynamic diameter, which dictates its various properties, including whether, where and how well it is deposited in the respiratory tree.

PM is composed of a mixture of organic and inorganic compounds along with various elements and ionic species (such as sulfate, nitrate, and ammonium ions). The ambient PM in any particular geographic location is affected by local mixtures of gaseous pollutants, topography, and seasonal weather and industry patterns. For example, PM may be influenced by seasonal changes in emission sources and atmospheric influences including wind speed, temperature, relative humidity, mixing height, and rainfall. ${ }^{10}$ As expected, the composition of PM influences its adverse health effects. PM may be primary or secondary: primary PM is man-made or natural and released directly into the environment, while secondary PM is composed of airborne compounds (e.g. organic carbon and sulfates) that have undergone photochemical reactions in the atmosphere. ${ }^{11}$

Urbanization and economic growth in many countries in Asia have increased industrial activities and motor vehicle emissions and as a result, caused air pollution to skyrocket. ${ }^{6,12}$ In Southeast Asia, seasonal haze from biomass burning has drawn international attention for its adverse effects on regional air quality and human health. The haze contains large quantities of airborne PM which can be carried great distances by prevailing winds and cause similar problems in other countries, including Indonesia, Malaysia, Brunei, Thailand, Singapore, and the Philippines. ${ }^{13}$

\section{Particulate matter and allergic respiratory diseases}

PM likely induces lung injury via multiple mechanisms, including ciliary dysfunction, epithelial cells damage, inflammation, and oxidative stress. ${ }^{14}$ The adverse health effects of PM10 and PM2.5 are the best established, but data are accumulating on the detrimental effects of ultrafine particles (UFPs) and nanoparticles. ${ }^{15}$ Over the past two decades, epidemiologic studies have estimated the association of PM with new-onset and exacerbation of allergic respiratory diseases. Although the Asia-Pacific region has developing countries with many large cities with high concentrations of ambient air pollutants, less epidemiologic data has been generated from this region compared to North America or Europe.

Clearly, PM may induce exacerbations in allergic respiratory diseases; however, there is less clarity around whether PM can cause these diseases to occur de novo. Differing case definitions, geographic region of study, air pollutants understudy, and methods used to estimate exposure dose and health effects make it difficult to compare results across studies.

Infants and young children are particularly susceptible to the adverse health effects of air pollution because of their immature immune and respiratory systems, they spend more time outdoors than people in other age groups, and they breathe more air per unit of body weight compared with adults. ${ }^{16-18}$ An association between PM exposure and new-onset allergic respiratory disease would be expected in these age groups. Therefore, a birth cohort study is considered the best available study design to investigate early childhood air pollutant exposure and the development of asthma and allergic disease. ${ }^{19}$ Such studies have been conducted globally but predominantly in North American and Europe. We summarize the available birth cohort studies addressing the association between particulate matter exposure and respiratory allergy in Table 1-2.

Table 1. Birth cohort studies addressing the association between particulate matter exposure and asthma incidence/prevalence

\begin{tabular}{|c|c|c|c|c|c|c|}
\hline $\begin{array}{l}\text { Name of original } \\
\text { cohort/database }\end{array}$ & $\begin{array}{l}\text { Author (Year of } \\
\text { publication) }\end{array}$ & $\begin{array}{c}\text { Year of } \\
\text { study start }\end{array}$ & Country & Exposure period & Pollutant & Outcome \\
\hline BAMSE & $\begin{array}{l}\text { Gruzieva } \\
(2013) \\
60\end{array}$ & $1994 / 1996$ & Sweden & First year of life & PM10 & $\begin{array}{l}\text { Increase asthma incidence at age } 12 \text { years } \\
\text { (aOR: } 2.39 ; 95 \% C I \text { 1.18-4.86, Exposure per } \\
2 \mu \mathrm{g} / \mathrm{m}^{3} \text { increase in PM10) }\end{array}$ \\
\hline CAPPS & $\begin{array}{l}\text { Carlsten } \\
(2011) \\
59\end{array}$ & 1995 & Canada & Birth addresses & PM2.5 & 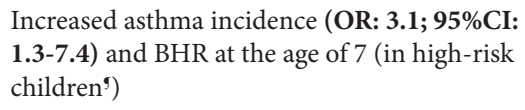 \\
\hline GINI/LISA & $\begin{array}{l}\text { Morgenstern } \\
(2008) \\
23\end{array}$ & $1995 / 1999$ & Germany & $\begin{array}{l}\text { Birth and current } \\
\text { addresses }\end{array}$ & PM2.5 & $\begin{array}{l}\text { No association with prevalence of asthma } \\
\text { until age } 6 \text { years }\end{array}$ \\
\hline GINI/LISAplus & $\begin{array}{l}\text { Gehring } \\
(2013) \\
93\end{array}$ & $1995 / 1999$ & Germany & $\begin{array}{l}\text { Birth and current } \\
\text { addresses }\end{array}$ & PM2.5 & $\begin{array}{l}\text { No association with prevalence of asthma } \\
\text { until age } 10-11 \text { years }\end{array}$ \\
\hline MAAS & $\begin{array}{l}\text { Molter } \\
(2015) \\
94\end{array}$ & $1995 / 1997$ & Great Britain & First year of life & PM10 & $\begin{array}{l}\text { No association with prevalence of either } \\
\text { asthma or wheeze until the age of } 11\end{array}$ \\
\hline
\end{tabular}


Table 1. (Continued)

\begin{tabular}{|c|c|c|c|c|c|c|}
\hline $\begin{array}{l}\text { Name of original } \\
\text { cohort/database }\end{array}$ & $\begin{array}{l}\text { Author (Year of } \\
\text { publication) }\end{array}$ & $\begin{array}{c}\text { Year of } \\
\text { study start }\end{array}$ & Country & Exposure period & Pollutant & Outcome \\
\hline PIAMA & $\begin{array}{l}\text { Gehring } \\
(2010,2015) \\
24,95\end{array}$ & $1996 / 1997$ & Netherlands & Birth addresses & PM2.5 & $\begin{array}{l}\text { Increased asthma incidence (aOR: } \mathbf{1 . 2 8} \text {; } \\
\mathbf{9 5 \% C I : ~ 1 . 1 0 - 1 . 4 9 ) ~ d u r i n g ~ t h e ~ f i r s t ~} 8 \text { years } \\
\text { of life } \\
\text { At age } 12 \text { years, lifetime risks of asthma } \\
\text { remained heightened. }\end{array}$ \\
\hline Data from QICDSS & $\begin{array}{l}\text { Tetreault } \\
(2016) \\
96\end{array}$ & $1996 / 2011$ & Canada & Birth addresses & PM2.5 & $\begin{array}{l}\text { Increased asthma incidence (HR: 1.31; } \\
\text { 95\%CI: 1.28-1.33) }\end{array}$ \\
\hline $\mathrm{BC}$ & $\begin{array}{l}\text { Clark } \\
(2010) \\
58\end{array}$ & $1999 / 2000$ & Canada & $\begin{array}{l}\text { Prenatal + First } \\
\text { year of life }\end{array}$ & PM10 & $\begin{array}{l}\text { Increased incidence of asthma up to } 3-4 \text { years } \\
\text { of age. (aOR: } 1.09 ; 95 \% \mathrm{CI}: 1.05-1.13 \text { in utero } \\
\text { exposure, aOR: } 1.07 ; 95 \% \mathrm{CI}: 1.03-1.12 \text { in } \\
\text { first-year exposure, per } 1 \mu \mathrm{g} / \mathrm{m}^{3} \text { increase in } \\
\text { PM10) }\end{array}$ \\
\hline $\begin{array}{l}\text { Data from British } \\
\text { Columbia Ministry } \\
\text { of Health }\end{array}$ & $\begin{array}{l}\text { Sbihi } \\
(2016) \\
97\end{array}$ & $1999 / 2002$ & Canada & Prenatal & PM10 & $\begin{array}{l}\text { Increased asthma incidence in pre-school } \\
\text { children (aOR: 1.12; 95\%CI: 1.05-1.19), not } \\
\text { in school-age children }\end{array}$ \\
\hline CHS & $\begin{array}{l}\text { McConnell } \\
(2010) \\
98\end{array}$ & $2002 / 2003$ & USA & Current exposure & $\begin{array}{l}\text { PM2.5, } \\
\text { PM10 }\end{array}$ & $\begin{array}{l}\text { No association with asthma incidence during } \\
3 \text { years of follow-up }\end{array}$ \\
\hline ACCESS & $\begin{array}{l}\text { Hsu } \\
(2015) \\
99\end{array}$ & $2002 / 2009$ & USA & Prenatal & PM2.5 & $\begin{array}{l}\text { Increased asthma incidence by the age of } 6 \\
\text { years in boys }\end{array}$ \\
\hline TMCHD & $\begin{array}{l}\text { Jung CR } \\
(2019) \\
100\end{array}$ & $2004 / 2011$ & Taiwan & $\begin{array}{l}\text { Prenatal }+ \text { First } \\
\text { year of life }\end{array}$ & PM2.5 & $\begin{array}{l}\text { Increased asthma incidence (HR of asthma } \\
\text { increased steeply at PM2.5 exposure }>93 \\
\mathbf{m g} / \mathbf{m}^{3} \text { ) during pregnancy, remained signifi- } \\
\text { cant with postnatal exposure to } 26-72 \mathrm{mg} / \mathrm{m}^{3}\end{array}$ \\
\hline CHEER & $\begin{array}{l}\text { Song-I Yang } \\
(2018) \\
101\end{array}$ & $2005 / 2006$ & Korea & $\begin{array}{l}\text { Prenatal + First } \\
\text { year of life }\end{array}$ & PM10 & $\begin{array}{l}\text { Increase asthma incidence (aOR: } 2.056 ; 95 \% \\
\text { CI: } 1.240-3.409 \text { ) in school-aged children }\end{array}$ \\
\hline
\end{tabular}

${ }^{*}$ Not include meta-analysis, and retrospective cohort studies

Abbreviations:

- aOR. Adjusted odd ratio;

- "High risk was defined as having first-degree relative with asthma or two first-degree relatives with other IgE-mediated allergic disease

- ACCESS, Asthma Coalition on Community, Environment and Social Stress

- BAMSE, Barn Allergi Miljö Stockholm Epidemiologi

- BC, British Columbia

- CAPPS, Canadian Asthma Primary Prevention Study

- CHS, The Southern California Children's Health Study

- CHEER, Children's HEalth and Environmental Research
Abbreviations (Continued):

- GINIplus, German Infant study on the influence of Nutrition Intervention plus environmental and genetic influences on allergy development

- LISAplus, Influence of Life style factors on the development of the Immune System and Allergies in East and West Germany plus the influence of traffic emissions and genetics

- MAAS, Manchester Asthma and Allergy Study

- MeDALL, Framework of the European collaborative Mechanisms of the Development of Allergy

- PIAMA, Prevention and Incidence of Asthma and Mite Allergy

- TMCHD, Taiwan Maternal and Child Health Database

Table 2. Birth cohort studies addressing the association between particulate matter exposure and allergic rhinitis/hay fever incidence/prevalence

\begin{tabular}{|c|c|c|c|c|c|c|}
\hline $\begin{array}{l}\text { Name of original } \\
\text { cohort/database }\end{array}$ & $\begin{array}{c}\text { Author (Year of } \\
\text { publication) }\end{array}$ & $\begin{array}{c}\text { Year of } \\
\text { study start }\end{array}$ & Country & Exposure period & Pollutant & Outcome \\
\hline $\begin{array}{l}\text { Four European birth } \\
\text { cohort (BAMSE, } \\
\text { GINIplus, LISAplus, } \\
\text { PIAMA) }\end{array}$ & $\begin{array}{l}\text { Gehring } \\
(2015) \\
102\end{array}$ & $1994 / 1999$ & Europe & $\begin{array}{l}\text { Birth and current } \\
\text { addresses }\end{array}$ & $\begin{array}{l}\text { PM2.5, } \\
\text { PM10 }\end{array}$ & $\begin{array}{l}\text { No association with allergic rhinitis incidence } \\
\text { and prevalence from age } 4 \text { years to } 14-16 \\
\text { years }\end{array}$ \\
\hline GINI \& LISA & $\begin{array}{l}\text { Morgenstern } \\
(2008) \\
23\end{array}$ & $1995 / 1999$ & Germany & $\begin{array}{l}\text { Birth and current } \\
\text { addresses }\end{array}$ & PM2.5 & No association with allergic rhinitis incidence \\
\hline
\end{tabular}

\section{Abbreviations:}

- BAMSE, Barn Allergi Miljö Stockholm Epidemiologi

- GINI, German Infant study on the influence of Nutrition Intervention

- GINIplus, German Infant study on the influence of Nutrition Intervention plus environmental and genetic influences on allergy development

- LISA, Influence of Life style factors on the development of the Immune System and Allergies in East and West Germany
Abbreviations (Continued):

- LISAplus, Influence of Life style factors on the development of the Immune System and Allergies in East and West Germany plus the influence of traffic emissions and genetics

- PIAMA, Prevention and Incidence of Asthma and Mite Allergy 


\section{Particulate matter and aeroallergen sensitization}

Allergic sensitization is generally defined as the development of IgE specific to one allergen and is a major risk factor for new-onset allergic respiratory disease..$^{20,21}$ The prevalence of aeroallergen sensitization pattern varies by region and country and results from studies aimed at assessing the association between PM and allergic sensitization are conflicting. ${ }^{22-24}$

Likewise, findings among birth cohort-based meta-analyses have been inconsistent. Bowatte, et al. reported a significant association between early childhood PM2.5 exposure and sensitization to outdoor aeroallergens but not indoor aeroallergens. ${ }^{25}$ A meta-analysis of 5 European birth cohorts showed no clear association between either PM2.5 or PM10 exposure and allergic sensitization in children aged up to 10 years; ${ }^{26}$ however, there was no adjustment for indoor aeroallergens and food allergens. In one study, investigators noted an association between PM2.5 exposure and sensitization to food allergens and outdoor aeroallergens, most commonly pollen. ${ }^{25}$ Among food items, the clearest risk factor was peanut allergens which are known to interact with pollens, including birch..$^{27}$

The biological plausibility of the etiologic association between PM and allergic sensitization is supported by experimental evidence indicating PM could enhance immunologic responses to allergens and induce inflammatory reactions in the airways. In a controlled-exposure study of atopic and nonatopic persons, nasal challenge with $0.3 \mathrm{mg}$ of diesel exhaust particles (DEP) increased IgE production in nasal mucosa at 4 days without effects on the other immunoglobulin isoforms. ${ }^{28}$ Compared with ragweed allergens alone, intranasal challenge with a combination of DEP and ragweed allergens induced markedly higher ragweed-specific IgE. ${ }^{29} \mathrm{~A}$ similar effect was also observed in lower respiratory tract. Over a 3-week period, repeated intratracheal challenge with a combination of house dust mites (HDM) and DEP induced a greater increase in HDM-specific IgE compared to challenge with HDM alone. ${ }^{30}$ The synergistic effect of DEP and aeroallergens is believed to be a key promoter of allergen-induced allergic respiratory disease. A series of controlled-exposure studies showed DEP affects multiple cell types, thus able to influence several important steps of the allergic cascade. ${ }^{31}$ Other air pollutants including ozone, nitrogen dioxide, and sulfur dioxide also have allergen enhancing effects. ${ }^{12}$

Air pollutants may enhance aeroallergen sensitization through multiple mechanisms including the following: carrying aeroallergens into the airways, inducing epithelial permeability by promoting oxidative stress and inflammation, increasing the antigenicity of allergens via chemical modification, and by acting as an immunologic adjuvant..$^{32,33}$

Although experimental studies suggest a causal association between PM exposure and outdoor aeroallergen sensitization, results from birth cohort studies have been inconsistent. In some studies, exposures below a putative sensitization threshold could mask the suggested association. ${ }^{22,24}$ Likewise, inadequate duration of exposure and heterogeneity in the susceptibility of hosts could also influence outcomes.

To date, questions around the effects of long-term exposure to PM on allergic sensitization in Asian populations remain unanswered. Several issues, including whether higher concentrations of ambient air pollutants significantly enter the indoor environment by ventilation or infiltration (thus, increasing the likelihood of allergic sensitization to indoor aeroallergens), need further investigation.

\section{Particulate matter and the development of allergic rhinitis}

Allergic rhinitis (AR) is a disease characterized by IgE-mediated inflammation of the nasal mucosa occurring when a person is exposed to an aeroallergen. The prevalence of AR has markedly increased in many countries, ${ }^{34}$ including many in the Asia-Pacific region. ${ }^{35,36}$ Human and animal studies reveal short-term exposure to PM may increase symptoms of $\mathrm{AR}$, but the role of PM in the development of AR is not well understood. ${ }^{32,37,38}$

Studies from North America and Europe suggested the prevalence of allergic diseases may be reaching a plateau, ${ }^{39,40}$ whereas developing countries in Asia-Pacific with strong economic growth have experienced a dramatic increase over the last few years. ${ }^{41}$ Urbanization is a known risk factor for respiratory allergies in children and young adults and is believed to be largely responsible for the uptick in prevalence in the AsiaPacific. ${ }^{42-45}$

The relationship between the development of AR and PM exposure is inconsistent. Comparing results across studies is made difficult by their differing study designs, study populations, case definitions, methods to estimate pollutant exposure, and other regional differences. In one meta-analysis of birth cohorts, there was no increased risk for AR from exposure to PM2.5 [OR: 1.02 per $2 \mu \mathrm{g} / \mathrm{m}^{3}$ increase in PM2.5 (95\% CI: $0.72-1.43)] .{ }^{46}$ In contrast, in another pooled meta-analysis of six birth cohorts, investigators observed an association between PM2.5 exposure at birth and AR diagnosis at the age of 7-8 years [OR: 1.37 per $5 \mu \mathrm{g} / \mathrm{m}^{3}$ increase in PM2.5 (95\%CI: 1.01 1.86).${ }^{47}$ In a subgroup (of children who did not move their house during their first 8 years of life) from a birth cohort of 3863 Dutch children, researchers found an association between PM2.5 exposure and AR. ${ }^{24}$

To date, published data from Asian birth cohorts on longterm PM exposure and the development of AR is scarce. Authors have published prospective, non-birth cohorts, some of which were cross-sectional and/or retrospective, and these have extensive methodological heterogeneity. ${ }^{48-53} \mathrm{~A}$ meta-analysis of Asian studies from 2000-2018 demonstrated an association between the prevalence of AR and PM exposure. ${ }^{54}$ Although PM can enhance immunologic responses to allergens and induce inflammatory reactions in human nasal mu$\operatorname{cosa}^{28,29,31}$ and animal models confirm the same, ${ }^{37}$ epidemiologic and experimental studies have not confirmed that PM induces the development of AR.

\section{Particulate matter and the development of asthma}

Asthma is a chronic airway disease characterized by airway inflammation, reversible airflow obstruction, and bronchial hyperresponsiveness. More than 300 million people suffer from asthma which results in approximately 250,000 deaths annually worldwide. ${ }^{55}$ The cause of asthma is believed to be a complex combination of multiple genetic and environmental factors leading to heterogeneous phenotypes. Although many epidemiologic studies have demonstrated a higher prevalence of asthma in many different regions of the world, the exact 
reasons remain unclear. ${ }^{56,57}$

Some evidence suggests PM contributes to asthma development, but findings are inconsistent. In most cohorts, the main source of air pollution was traffic-related (TRAP). ${ }^{24,58-60}$ A meta-analysis of birth cohort studies from North American and Europe showed increased longitudinal childhood exposure to PM2.5 was significantly associated with the incidence of asthma [OR 1.14 per $2 \mu \mathrm{g} / \mathrm{m}^{3}$ (95\%CI 1.0-1.3)], ${ }^{25}$ whereas another recent meta-analysis of birth cohort revealed no significant association. ${ }^{61}$ In another meta-analysis of cohort studies, long-term exposure to PM2.5 was associated with asthma incidence and wheezing; however, the analysis included both children and adults and did not separately consider the potentially important different effects related to exposure to TRAP in children. ${ }^{62}$

There is great heterogeneity across Asian studies. Although there were a few prospective birth cohort studies from Asia, many ongoing studies had been conducting to address this issue. A recent prospective birth cohort study that included 184,604 children from Taiwan demonstrated that increased exposure to PM2.5 during the prenatal (gestational weeks 6-22 weeks) or postnatal period (9-46 weeks post-partum) was associated with increased asthma incidence. Interestingly, the risk of asthma sharply increased when PM2.5 exposure was greater than $93 \mu \mathrm{g} / \mathrm{m}^{3}$ during pregnancy. ${ }^{63}$
Results from studies aimed at estimating the association between residential proximity to major roads and asthma prevalence have been inconsistent. The evidence is more consistent for the association between asthma prevalence and residence on roads carrying large amounts of truck traffic. ${ }^{33} \mathrm{~A}$ case-control study in the United Kingdom of 6,147 children living within 150 meters of the main road showed the risk of wheeze increased with increasing proximity [OR: 1.18 per 30 meters in primary school children (95\%CI: $1.00-1.16)$ and OR: 1.16 per 30 meters in secondary school children $(95 \% \mathrm{CI}$ : 1.02-1.32)]. Most of the increased risk was localized to within 90 meters from the roadside. ${ }^{64}$ However, results from Japan did not support an association between roadside exposure and asthma prevalence. ${ }^{65}$

Molecular mechanisms and gene-environment interactions have been hypothesized to explain how air pollution could contribute to the development of asthma. It is likely that a host of genetic factors and PM and aeroallergen exposures could play a role in the pathogenesis of asthma. ${ }^{33}$ We summarize these interactions in Figure 2.

Evidence, including from meta-analyses and mechanistic studies, shows ambient PM might play a role in causing asthma in susceptible individuals. Living near busy roads may increase the risk of asthma. A growing body of evidence suggests that exposure to TRAP accounts for many cases of asthma,

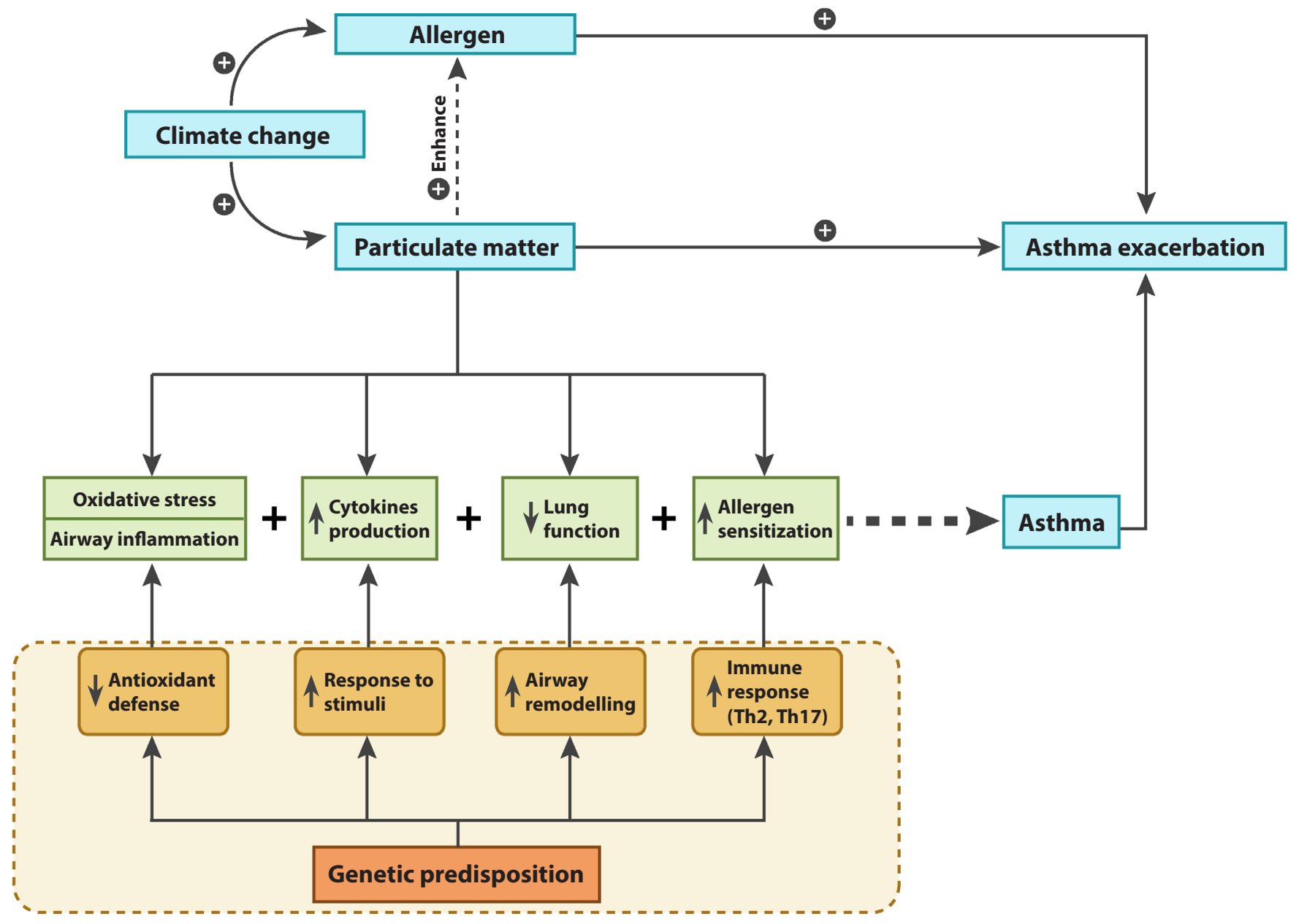

Figure 2. Model showing the possible interactions between genetics, particulate matter exposure, and aeroallergen exposure in asthma pathogenesis 
although given the complex pathogenesis of asthma, other mechanisms are probably involved. More long-term, well-designed prospective cohort studies may provide conclusive evidence.

\section{Particulate matter and asthmatic exacerbation}

It is universally accepted that air pollution exposure is associated with exacerbations of asthma. ${ }^{33}$ In 2015, 5-10 million emergency room visits globally could be attributable to PM2.5. Anthropogenic emissions were responsible for $73 \%$ of PM2.5. ${ }^{66}$ Whether short-term, peak exposure to PM (e.g. in 1 hour) versus a longer average exposure (e.g. over a few days) is more strongly associated with asthmatic exacerbation remains unclear. Some evidence has shown peak exposure is more important than average longer-term exposure. ${ }^{67}$ The existence of a lag period between exposure to PM and asthmatic exacerbation needs to be explored. ${ }^{7}$

Short-term exposure to ambient PM2.5 and PM2.5-10 in asthmatic children and adults has been associated with asthmatic symptoms in prospective cohort studies. ${ }^{68,69}$ Long-term exposure to PM is also associated with uncontrolled asthma and decrements in lung function in both children and adults. ${ }^{70,71}$ A meta-analysis of time-series studies showed shortterm exposure to PM10 and PM2.5 increased the risk of asthma-related emergency room visits and hospitalizations.?

A meta-analysis focusing on the data from Asia found that short-term exposure to air pollution was associated with increased risk of hospital utilization for asthma and chronic obstructive pulmonary disease (COPD) in the whole population. ${ }^{72}$ The association between PM and asthma exacerbations has also been supported by many experimental studies. In mouse models, exposure to PM resulted in allergic inflammation with Th2 and Th17 differentiation. ${ }^{73,74}$ DEP exposure could exacerbate allergic asthma and airway inflammation, which is partly dependent on IL-17A. ${ }^{30}$ In human challenge studies, the instillation of $100 \mu \mathrm{g}$ of PM2.5 suspension into the lungs of healthy volunteers could also cause mild airway inflammation in healthy volunteers. ${ }^{75}$

Studies have demonstrated inflammation and oxidative stress in the human lower respiratory tract after exposure to PM. DEP can stimulate respiratory reflexes by activation of afferent, airway, chemo-sensitive C-fibers. Interactions between DEP and these afferents are mediated through an oxidative stress pathway that activates the transient receptor potential ankyrin-1 (TRPA1) ion channel. ${ }^{76}$ Personal monitoring and implementation of an early action plan may reduce the frequency or severity of exacerbations due to PM.

\section{Particulate matter and its pathophysiologic effects in the respi- ratory system}

After inhalation, PM2.5 deposits in the deep airway and alveoli where it can cause structural damage and impair regular respiratory function. Published data has shown the association between PM2.5 exposure and effects on various respiratory diseases, such as asthma, COPD, and lung cancer. ${ }^{33}$

PM2.5 exposure has effects on the human respiratory system, including altering the immune response, inducing oxidative stress, and producing inflammation. ${ }^{77}$ Alteration of immune response results from inducing transcription factors for stimulating cytokines that induce up-regulation of cell apoptosis, increase reactive oxygen species (ROS), and interrupt mitochondrial function. ${ }^{78,79} \mathrm{PM} 2.5$ exposure induces oxidative stress by increasing ROS and modifying cellular permeability. These ROS then further activate the inflammatory response and contribute to epithelial barrier dysfunction. ${ }^{80}$ PM2.5 exposure also reduces transcription of antioxidant enzymes, intensifying the oxidant-antioxidant imbalance. ${ }^{81,82}$ PM2.5 accumulation on airway epithelium can trigger the inflammatory signaling cascade, thereby inducing systemic immunological responses and inflammation. ${ }^{83,84}$

In addition, PM2.5 exposure may cause NK-cell dysfunction, and these cells are needed for eradicating Staphylococcus aureus infection..$^{85}$ This may contribute to the association between increases in ambient air pollution exposure and increasing pulmonary bacterial infection rates.

\section{The contribution of outdoor particulate matter to indoor air quality}

Most urban residents spend more than $80 \%$ of daily life indoors. ${ }^{86}$ Therefore, the majority exposure to any airborne substance should occur there. Because ambient PM penetrates from comes indoors through ventilation systems and building leaks, researchers have focused on the relationship between indoor and ambient PM concentrations in various settings. ${ }^{87}$ The indoor PM2.5 concentrations correlate with ambient PM2.5 concentrations in many studies. ${ }^{87-89}$

The relationship between indoor exposure to PM2.5 and asthma symptoms is similar to outdoor exposure. High indoor levels of PM2.5 were associated with acute respiratory symptoms and lung function impairment. ${ }^{90}$ Similar results were observed in a Peruvian study involving 1441 adolescents aged 13-15 years; this study showed that living in a peri-urban setting, where indoor PM concentrations were elevated, was associated with asthma, atopy, and airway inflammation. ${ }^{44}$

$\mathrm{PM}$ reduction can improve health conditions in asthmatic subjects. A randomized controlled study showed that reducing indoor PM concentrations by using air cleaners was associated with a significant increase in symptom-free days in children with asthma. ${ }^{91}$

Indoor dwellers are still at risk from the adverse health effects of PM2.5. Efforts should focus on reducing ambient and indoor PM2.5. Currently, the contributions of air pollutant exposure within indoor environments, such as homes, schools, work offices, and enclosed modes of transportation, are understudied. New technologies might allow for assessment of exposure in these locations. ${ }^{92}$

\section{Conclusion}

Air pollution is a major problem with adverse health effects. A large and growing body of evidence supports the causal association between PM exposure and exacerbations of allergic respiratory disease, while an increasing body of evidence suggests long-term exposure to PM could contribute to the development of the allergic respiratory disease. We have concluded the causal association according to the cumulative of evidence in Table 3. Additional, well-designed studies are needed, especially from the Asia-Pacific region where the concentrations of ambient air pollution are much higher and 
Table 3. The contribution of particulate matter to respiratory allergies according to recent evidence

\begin{tabular}{|c|c|c|c|c|c|}
\hline Respiratory allergies & $\begin{array}{l}\text { Epidemiological } \\
\text { studies results }\end{array}$ & $\begin{array}{l}\text { Birth cohort } \\
\text { studies } \\
\text { results }\end{array}$ & Conclusion from meta-analysis & $\begin{array}{l}\text { Experimental } \\
\text { studies }\end{array}$ & $\begin{array}{l}\text { Conclusion } \\
\text { of causal } \\
\text { association }^{*}\end{array}$ \\
\hline Aeroallergen sensitization & Inconsistent & Inconsistent & $\begin{array}{l}\text { - Inconsistent }{ }^{25,26} \\
\text { - Significant association with outdoor aeroaller- } \\
\text { gen, but not indoor aeroallergen (birth cohort) } \\
\text { - No significant association }\end{array}$ & Supportive $e^{28-31}$ & Possible \\
\hline Asthma incidence/prevalence & Inconsistent & Inconsistent & $\begin{array}{l}\text { - Inconsistent } \\
\text { - Positive association (birth cohort) }{ }^{25} \\
\text { - No significant association (birth cohort) }{ }^{61}\end{array}$ & Supportive ${ }^{30,33}$ & Probable \\
\hline $\begin{array}{l}\text { Allergic rhinitis incidence/ } \\
\text { prevalence }\end{array}$ & Inconsistent & Inconsistent & 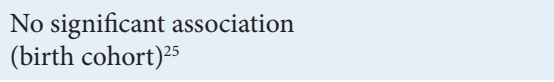 & Supportive $e^{28,29,31,37}$ & Possible \\
\hline Asthmatic exacerbation & $\begin{array}{l}\text { High degree of } \\
\text { consistency from } \\
\text { time-series and } \\
\text { case-crossover } \\
\text { studies }\end{array}$ & - & $\begin{array}{l}\text { Increase risk (time-series and case-cross- } \\
\text { over) }{ }^{103,104}\end{array}$ & Supportive $\mathrm{e}^{30,73-75}$ & High \\
\hline
\end{tabular}

*The conclusions are based on the combination of both epidemiological research and experimental studies.

rising as urbanization increases in the region. For these populations, the development and implementation of governmental policies to improve air quality would not only improve the quality of life for individual citizens, but it would also reduce the threat of a looming allergic respiratory disease epidemic.

\section{Acknowledgment}

We would like to thank Dr. Anthony Tan for editing the English language. We also thank Mrs. Sanyaluck Wattanachalermyos for the graphic design of the figures.

\section{References}

1. WHO in South-East Asia [Internet]. New Delhi: World Health Organization, South-East Asia Regional Office (SEARO); c2019. What is Air Pollution?; 2018 [cited 2019 Jun 1]; [2 p.]. Available from: http://www. searo.who.int/topics/air_pollution/what-is-air-pollution.pdf?ua $=1$

2. Li G, Fang C, Wang S, Sun S. The Effect of Economic Growth, Urbanization, and Industrialization on Fine Particulate Matter (PM2.5) Concentrations in China. Environ Sci Technol. 2016;50:11452-9.

3. Landrigan PJ, Fuller R, Acosta NJR, Adeyi O, Arnold R, Basu NN, et al. The Lancet Commission on pollution and health. Lancet. 2018;391: 462-512.

4. Anderson HR, Gupta R, Strachan DP, Limb ES. 50 years of asthma: UK trends from 1955 to 2004. Thorax. 2007;62:85-90.

5. Wise SK, Lin SY, Toskala E, Orlandi RR, Akdis CA, Alt JA, et al. International Consensus Statement on Allergy and Rhinology: Allergic Rhinitis. Int Forum Allergy Rhinol. 2018;8:108-352.

6. Chung KF, Zhang J, Zhong N. Outdoor air pollution and respiratory health in Asia. Respirology. 2011;16:1023-6.

7. Zheng XY, Ding H, Jiang LN, Chen SW, Zheng JP, Qiu M, et al. Association between Air Pollutants and Asthma Emergency Room Visits and Hospital Admissions in Time Series Studies: A Systematic Review and Meta-Analysis. PLoS One. 2015;10:e138146.

8. Zhang Q, Qiu Z, Chung KF, Huang SK. Link between environmental air pollution and allergic asthma: East meets West. J Thorac Dis. 2015;7: 14-22.

9. World Health Organization (WHO). WHO Air quality guidelines for particulate matter, ozone, nitrogen dioxide and sulfur dioxide: global update 2005: summary of risk assessment. Geneva: World Health Organization; 2004. 20 p.

10. Behera SN, Sharma M. Reconstructing Primary and Secondary Components of PM2.5 Composition for an Urban Atmosphere. Aerosol Science and Technology. 2010;44:983-92.
11. Feng JL, Guo ZG, Zhang TR, Yao XH, Chan CK, Fang M. Source and formation of secondary particulate matter in PM2.5 in Asian continental outflow. J Geophys Res Atmos. 2012;117.

12. Guan WJ, Zheng XY, Chung KF, Zhong NS. Impact of air pollution on the burden of chronic respiratory diseases in China: time for urgent action. Lancet. 2016;388:1939-51.

13. Ho RC, Zhang MW, Ho CS, Pan F, Lu Y, Sharma VK. Impact of 2013 south Asian haze crisis: study of physical and psychological symptoms and perceived dangerousness of pollution level. BMC Psychiatry. 2014;14:81.

14. Ciencewicki J, Trivedi S, Kleeberger SR. Oxidants and the pathogenesis of lung diseases. J Allergy Clin Immunol. 2008;122:456-68.

15. Li N, Georas S, Alexis N, Fritz P, Xia T, Williams MA, et al. A work group report on ultrafine particles (American Academy of Allergy, Asthma \& Immunology): Why ambient ultrafine and engineered nanoparticles should receive special attention for possible adverse health outcomes in human subjects. J Allergy Clin Immunol. 2016;138:386-96.

16. Wright RJ, Brunst KJ. Programming of respiratory health in childhood: influence of outdoor air pollution. Curr Opin Pediatr. 2013;25:232-9.

17. Trasande L, Thurston GD. The role of air pollution in asthma and other pediatric morbidities. J Allergy Clin Immunol. 2005;115:689-99.

18. Dietert RR, Etzel RA, Chen D, Halonen M, Holladay SD, Jarabek AM, et al. Workshop to identify critical windows of exposure for children's health: immune and respiratory systems work group summary. Environ Health Perspect. 2000;108 Suppl 3:483-90.

19. Bousquet J, Gern JE, Martinez FD, Anto JM, Johnson CC, Holt PG, et al. Birth cohorts in asthma and allergic diseases: report of a NIAID/NHLBI/ MeDALL joint workshop. J Allergy Clin Immunol. 2014;133:1535-46.

20. Leung R, Ho P, Lam CW, Lai CK. Sensitization to inhaled allergens as a risk factor for asthma and allergic diseases in Chinese population. J Allergy Clin Immunol. 1997;99:594-9.

21. Arshad SH, Tariq SM, Matthews S, Hakim E. Sensitization to common allergens and its association with allergic disorders at age 4 years: a whole population birth cohort study. Pediatrics. 2001;108:E33.

22. Gruzieva O, Bellander T, Eneroth K, Kull I, Melen E, Nordling E, et al. Traffic-related air pollution and development of allergic sensitization in children during the first 8 years of life. J Allergy Clin Immunol. 2012; 129:240-6.

23. Morgenstern V, Zutavern A, Cyrys J, Brockow I, Koletzko S, Kramer U, et al. Atopic diseases, allergic sensitization, and exposure to traffic-related air pollution in children. Am J Respir Crit Care Med. 2008;177:1331-7.

24. Gehring U, Wijga AH, Brauer M, Fischer P, de Jongste JC, Kerkhof M, et al. Traffic-related air pollution and the development of asthma and allergies during the first 8 years of life. Am J Respir Crit Care Med. 2010;181: 596-603.

25. Bowatte G, Lodge C, Lowe AJ, Erbas B, Perret J, Abramson MJ, et al. The influence of childhood traffic-related air pollution exposure on asthma, allergy and sensitization: a systematic review and a meta-analysis of birth cohort studies. Allergy. 2015;70:245-56. 
26. Gruzieva O, Gehring U, Aalberse R, Agius R, Beelen R, Behrendt H, et al. Meta-analysis of air pollution exposure association with allergic sensitization in European birth cohorts. J Allergy Clin Immunol. 2014; 133:767-76 e7.

27. Asarnoj A, Ostblom E, Ahlstedt S, Hedlin G, Lilja G, van Hage M, et al. Reported symptoms to peanut between 4 and 8 years among children sensitized to peanut and birch pollen - results from the BAMSE birth cohort. Allergy. 2010;65:213-9.

28. Diaz-Sanchez D, Dotson AR, Takenaka H, Saxon A. Diesel exhaust particles induce local IgE production in vivo and alter the pattern of $\operatorname{IgE}$ messenger RNA isoforms. J Clin Invest. 1994;94:1417-25.

29. Diaz-Sanchez D, Tsien A, Fleming J, Saxon A. Combined diesel exhaust particulate and ragweed allergen challenge markedly enhances human in vivo nasal ragweed-specific IgE and skews cytokine production to a $\mathrm{T}$ helper cell 2-type pattern. J Immunol. 1997;158:2406-13.

30. Brandt EB, Kovacic MB, Lee GB, Gibson AM, Acciani TH, Le Cras TD, et al. Diesel exhaust particle induction of IL-17A contributes to severe asthma. J Allergy Clin Immunol. 2013;132:1194-204 e2.

31. Riedl M, Diaz-Sanchez D. Biology of diesel exhaust effects on respiratory function. J Allergy Clin Immunol. 2005;115:221-8.

32. Diaz-Sanchez D, Penichet-Garcia M, Saxon A. Diesel exhaust particles directly induce activated mast cells to degranulate and increase histamine levels and symptom severity. J Allergy Clin Immunol. 2000;106:1140-6.

33. Gowers AM, Cullinan P, Ayres JG, Anderson HR, Strachan DP, Holgate ST, et al. Does outdoor air pollution induce new cases of asthma? Biological plausibility and evidence; a review. Respirology. 2012;17:887-98.

34. Asher MI, Montefort S, Bjorksten B, Lai CK, Strachan DP, Weiland SK, et al. Worldwide time trends in the prevalence of symptoms of asthma, allergic rhinoconjunctivitis, and eczema in childhood: ISAAC Phases One and Three repeat multicountry cross-sectional surveys. Lancet. 2006; 368:733-43.

35. Trakultivakorn M, Sangsupawanich P, Vichyanond P. Time trends of the prevalence of asthma, rhinitis and eczema in Thai children-ISAAC (International Study of Asthma and Allergies in Childhood) Phase Three. J Asthma. 2007;44:609-11.

36. Huang C, Liu W, Hu Y, Zou Z, Zhao Z, Shen L, et al. Updated prevalences of asthma, allergy, and airway symptoms, and a systematic review of trends over time for childhood asthma in Shanghai, China. PLoS One. 2015; 10:e0121577.

37. Wang YL, Gao W, Li Y, Wang YF. Concentration-dependent effects of PM2.5 mass on expressions of adhesion molecules and inflammatory cytokines in nasal mucosa of rats with allergic rhinitis. Eur Arch Otorhinolaryngol. 2017;274:3221-9.

38. Wu JZ, Ge DD, Zhou LF, Hou LY, Zhou Y, Li QY. Effects of particulate matter on allergic respiratory diseases. Chronic Dis Transl Med. 2018; 4:95-102.

39. Braun-Fahrlander C, Gassner M, Grize L, Takken-Sahli K, Neu U, Stricker $\mathrm{T}$, et al. No further increase in asthma, hay fever and atopic sensitisation in adolescents living in Switzerland. Eur Respir J. 2004;23:407-13.

40. Verlato G, Corsico A, Villani S, Cerveri I, Migliore E, Accordini S, et al. Is the prevalence of adult asthma and allergic rhinitis still increasing? Results of an Italian study. J Allergy Clin Immunol. 2003;111:1232-8.

41. Singh M. The burden of asthma in children: an Asian perspective. Paediatr Respir Rev. 2005;6:14-9.

42. Song WJ, Sohn KH, Kang MG, Park HK, Kim MY, Kim SH, et al. Urban-rural differences in the prevalence of allergen sensitization and self-reported rhinitis in the elderly population. Ann Allergy Asthma Immunol. 2015;114:455-61.

43. Lee SY, Kwon JW, Seo JH, Song YH, Kim BJ, Yu J, et al. Prevalence of atopy and allergic diseases in Korean children: associations with a farming environment and rural lifestyle. Int Arch Allergy Immunol. 2012;158:168-74.

44. Robinson CL, Baumann LM, Romero K, Combe JM, Gomez A, Gilman RH, et al. Effect of urbanisation on asthma, allergy and airways inflammation in a developing country setting. Thorax. 2011;66:1051-7.

45. Majkowska-Wojciechowska B, Pelka J, Korzon L, Kozlowska A, Kaczala M, Jarzebska M, et al. Prevalence of allergy, patterns of allergic sensitization and allergy risk factors in rural and urban children. Allergy. 2007;62: 1044-50.

46. Heinrich J. Air pollutants and primary allergy prevention. Allergo J Int. 2019:28;5-15.
47. Fuertes E, Brauer M, MacIntyre E, Bauer M, Bellander T, von Berg A, et al. Childhood allergic rhinitis, traffic-related air pollution, and variability in the GSTP1, TNF, TLR2, and TLR4 genes: results from the TAG Study. J Allergy Clin Immunol. 2013;132:342-52.

48. Chung HY, Hsieh CJ, Tseng CC, Yiin LM. Association between the First Occurrence of Allergic Rhinitis in Preschool Children and Air Pollution in Taiwan. Int J Environ Res Public Health. 2016;13.

49. Liu W, Huang C, Hu Y, Fu Q, Zou Z, Sun C, et al. Associations of gestational and early life exposures to ambient air pollution with childhood respiratory diseases in Shanghai, China: A retrospective cohort study. Environ Int. 2016;92-93:284-93

50. Deng Q, Lu C, Yu Y, Li Y, Sundell J, Norback D. Early life exposure to traffic-related air pollution and allergic rhinitis in preschool children. Respir Med. 2016;121:67-73.

51. Wang IJ, Tung TH, Tang CS, Zhao ZH. Allergens, air pollutants, and childhood allergic diseases. Int J Hyg Environ Health. 2016;219:66-71.

52. Chen F, Lin Z, Chen R, Norback D, Liu C, Kan H, et al. The effects of PM2.5 on asthmatic and allergic diseases or symptoms in preschool children of six Chinese cities, based on China, Children, Homes and Health $(\mathrm{CCHH})$ project. Environ Pollut. 2018;232:329-37.

53. Norback D, Lu C, Wang J, Zhang Y, Li B, Zhao Z, et al. Asthma and rhinitis among Chinese children - Indoor and outdoor air pollution and indicators of socioeconomic status (SES). Environ Int. 2018;115:1-8.

54. Zou QY, Shen Y, Ke X, Hong SL, Kang HY. Exposure to air pollution and risk of prevalence of childhood allergic rhinitis: A meta-analysis. Int J Pediatr Otorhinolaryngol. 2018;112:82-90.

55. Ozdoganoglu T, Songu M. The burden of allergic rhinitis and asthma. Ther Adv Respir Dis. 2012;6:11-23.

56. Downs SH, Marks GB, Sporik R, Belosouva EG, Car NG, Peat JK Continued increase in the prevalence of asthma and atopy. Arch Dis Child. 2001;84:20-3.

57. Burney P. The changing prevalence of asthma? Thorax. 2002;57 Suppl 2:II36-II9.

58. Clark NA, Demers PA, Karr CJ, Koehoorn M, Lencar C, Tamburic L, et al Effect of early life exposure to air pollution on development of childhood asthma. Environ Health Perspect. 2010;118:284-90.

59. Carlsten C, Dybuncio A, Becker A, Chan-Yeung M, Brauer M Traffic-related air pollution and incident asthma in a high-risk birth cohort. Occup Environ Med. 2011;68:291-5.

60. Gruzieva O, Bergstrom A, Hulchiy O, Kull I, Lind T, Melen E, et al Exposure to air pollution from traffic and childhood asthma until 12 years of age. Epidemiology. 2013;24:54-61.

61. Molter A, Simpson A, Berdel D, Brunekreef B, Custovic A, Cyrys J, et al. A multicentre study of air pollution exposure and childhood asthma prevalence: the ESCAPE project. Eur Respir J. 2015;45:610-24.

62. Anderson HR, Favarato G, Atkinson RW. Long-term exposure to air pollution and the incidence of asthma: Meta-analysis of cohort studies. Air Qual Atmos Health. 2011;6:1-10.

63. Jung CR, Chen WT, Tang YH, Hwang BF. Fine particulate matter exposure during pregnancy and infancy and incident asthma. J Allergy Clin Immunol. 2019;143:2254-62.e5.

64. Venn AJ, Lewis SA, Cooper M, Hubbard R, Britton J. Living near a main road and the risk of wheezing illness in children. Am J Respir Crit Care Med. 2001;164:2177-80.

65. Shima M, Nitta Y, Adachi M. Traffic-related air pollution and respiratory symptoms in children living along trunk roads in Chiba Prefecture, Japan. J Epidemiol. 2003;13:108-19.

66. Anenberg SC, Henze DK, Tinney V, Kinney PL, Raich W, Fann N, et al. Estimates of the Global Burden of Ambient PM2.5, Ozone, and $\mathrm{NO}_{2}$ on Asthma Incidence and Emergency Room Visits. Environ Health Perspect. 2018;126:107004

67. Delfino RJ, Staimer N, Tjoa T, Gillen D, Kleinman MT, Sioutas C, et al. Personal and ambient air pollution exposures and lung function decrements in children with asthma. Environ Health Perspect. 2008;116: 550-8.

68. Mann JK, Balmes JR, Bruckner TA, Mortimer KM, Margolis HG, Pratt B, et al. Short-term effects of air pollution on wheeze in asthmatic children in Fresno, California. Environ Health Perspect. 2010;118:1497-502.

69. Meng YY, Rull RP, Wilhelm M, Lombardi C, Balmes J, Ritz B. Outdoor air pollution and uncontrolled asthma in the San Joaquin Valley, California. J Epidemiol Community Health. 2010;64:142-7. 
70. Liu L, Poon R, Chen L, Frescura AM, Montuschi P, Ciabattoni G, et al. Acute effects of air pollution on pulmonary function, airway inflammation, and oxidative stress in asthmatic children. Environ Health Perspect. 2009;117:668-74.

71. Jacquemin B, Kauffmann F, Pin I, Le Moual N, Bousquet J, Gormand F, et al. Air pollution and asthma control in the Epidemiological study on the Genetics and Environment of Asthma. J Epidemiol Community Health. 2012;66:796-802.

72. Zhang S, Li G, Tian L, Guo Q, Pan X. Short-term exposure to air pollution and morbidity of COPD and asthma in East Asian area: A systematic review and meta-analysis. Environ Res. 2016;148:15-23.

73. Wang P, Thevenot P, Saravia J, Ahlert T, Cormier SA. Radical-containing particles activate dendritic cells and enhance Th17 inflammation in a mouse model of asthma. Am J Respir Cell Mol Biol. 2011;45:977-83.

74. van Voorhis M, Knopp S, Julliard W, Fechner JH, Zhang X, Schauer JJ, et al. Exposure to atmospheric particulate matter enhances Th17 polarization through the aryl hydrocarbon receptor. PLoS One. 2013;8:e82545.

75. Schaumann F, Borm PJ, Herbrich A, Knoch J, Pitz M, Schins RP, et al. Metal-rich ambient particles (particulate matter 2.5) cause airway inflammation in healthy subjects. Am J Respir Crit Care Med. 2004; 170:898-903.

76. Robinson RK, Birrell MA, Adcock JJ, Wortley MA, Dubuis ED, Chen S, et al. Mechanistic link between diesel exhaust particles and respiratory reflexes. J Allergy Clin Immunol. 2018;141:1074-84 e9.

77. Li T, Hu R, Chen Z, Li Q, Huang S, Zhu Z, et al. Fine particulate matter (PM2.5): The culprit for chronic lung diseases in China. Chronic Dis Transl Med. 2018;4:176-86.

78. Zhang Y, Wang S, Zhu J, Li C, Zhang T, Liu H, et al. Effect of Atmospheric PM2.5 on Expression Levels of NF- $\kappa B$ Genes and Inflammatory Cytokines Regulated by NF- $\kappa \mathrm{B}$ in Human Macrophage. Inflammation. 2018;41:784-94.

79. Rylance J, Fullerton DG, Scriven J, Aljurayyan AN, Mzinza D, Barrett S, et al. Household air pollution causes dose-dependent inflammation and altered phagocytosis in human macrophages. Am J Respir Cell Mol Biol. 2015;52:584-93

80. Yang L, Liu G, Lin Z, Wang Y, He H, Liu T, et al. Pro-inflammatory response and oxidative stress induced by specific components in ambient particulate matter in human bronchial epithelial cells. Environ Toxicol. 2016;31:923-36

81. Lawal AO. Air particulate matter induced oxidative stress and inflammation in cardiovascular disease and atherosclerosis: The role of Nrf2 and AhR-mediated pathways. Toxicol Lett. 2017;270:88-95.

82. Cachon BF, Firmin S, Verdin A, Ayi-Fanou L, Billet S, Cazier F, et al. Proinflammatory effects and oxidative stress within human bronchial epithelial cells exposed to atmospheric particulate matter $(\operatorname{PM}(2.5)$ and $\operatorname{PM}(>2.5)$ ) collected from Cotonou, Benin. Environ Pollut. 2014;185: 340-51.

83. He M, Ichinose T, Yoshida S, Ito T, He C, Yoshida Y, et al. PM2.5-induced lung inflammation in mice: Differences of inflammatory response in macrophages and type II alveolar cells. J Appl Toxicol. 2017;37:1203-18.

84. He M, Ichinose T, Yoshida Y, Arashidani K, Yoshida S, Takano H, et al Urban PM2.5 exacerbates allergic inflammation in the murine lung via a TLR2/TLR4/MyD88-signaling pathway. Sci Rep. 2017;7:11027.

85. Zhao H, Li W, Gao Y, Li J, Wang H. Exposure to particular matter increases susceptibility to respiratory Staphylococcus aureus infection in rats via reducing pulmonary natural killer cells. Toxicology. 2014;325: 180-8.

86. McCormack MC, Breysse PN, Matsui EC, Hansel NN, Peng RD, Curtin-Brosnan J, et al. Indoor particulate matter increases asthma morbidity in children with non-atopic and atopic asthma. Ann Allergy Asthma Immunol. 2011;106:308-15.
87. Chen C, Zhao B. Review of relationship between indoor and outdoor particles: I/O ratio, infiltration factor and penetration factor. Atmospheric Environment. 2011;45:275-88.

88. Sompornrattanaphan M, Thongngarm T, Tantilipikorn P, Kreetapirom P, Foo J. The Contribution of Outdoor Fine Particulate Matter to Indoor Air Quality in Bangkok Metropolitan Region, Thailand - Are Indoor Dwellers Safe? Siriraj Medical J. 2018;70:265-71.

89. Tsai FC, Smith KR, Vichit-Vadakan N, Ostro BD, Chestnut LG Kungskulniti N. Indoor/outdoor PM10 and PM2.5 in Bangkok, Thailand. J Expo Anal Environ Epidemiol. 2000;10:15-26.

90. Simoni M, Scognamiglio A, Carrozzi L, Baldacci S, Angino A, Pistelli $\mathrm{F}$, et al. Indoor exposures and acute respiratory effects in two general population samples from a rural and an urban area in Italy. J Expo Anal Environ Epidemiol. 2004;14 Suppl 1:S144-52.

91. Butz AM, Matsui EC, Breysse P, Curtin-Brosnan J, Eggleston P, Diette G, et al. A randomized trial of air cleaners and a health coach to improve indoor air quality for inner-city children with asthma and secondhand smoke exposure. Arch Pediatr Adolesc Med. 2011;165:741-8.

92. Adams C, Riggs P, Volckens J. Development of a method for personal, spatiotemporal exposure assessment. J Environ Monit. 2009;11:1331-9.

93. Fuertes E, Standl M, Cyrys J, Berdel D, von Berg A, Bauer CP, et al. A longitudinal analysis of associations between traffic-related air pollution with asthma, allergies and sensitization in the GINIplus and LISAplus birth cohorts. PeerJ. 2013;1:e193.

94. Molter A, Agius R, de Vocht F, Lindley S, Gerrard W, Custovic A, et al. Effects of long-term exposure to PM10 and NO2 on asthma and wheeze in a prospective birth cohort. J Epidemiol Community Health. 2014;68:21-8.

95. Gehring U, Beelen R, Eeftens M, Hoek G, de Hoogh K, de Jongste JC, et al. Particulate matter composition and respiratory health: the PIAMA Birth Cohort study. Epidemiology. 2015;26:300-9.

96. Tetreault LF, Doucet M, Gamache P, Fournier M, Brand A, Kosatsky T, et al. Childhood Exposure to Ambient Air Pollutants and the Onset of Asthma: An Administrative Cohort Study in Quebec. Environ Health Perspect. 2016;124:1276-82.

97. Sbihi H, Tamburic L, Koehoorn M, Brauer M. Perinatal air pollution exposure and development of asthma from birth to age 10 years. Eur Respir J. 2016;47:1062-71.

98. McConnell R, Islam T, Shankardass K, Jerrett M, Lurmann F, Gilliland F, et al. Childhood incident asthma and traffic-related air pollution at home and school. Environ Health Perspect. 2010;118:1021-6.

99. Hsu HH, Chiu YH, Coull BA, Kloog I, Schwartz J, Lee A, et al. Prenatal Particulate Air Pollution and Asthma Onset in Urban Children. Identifying Sensitive Windows and Sex Differences. Am J Respir Crit Care Med. 2015;192:1052-9.

100.Jung CR, Chen WT, Tang YH, Hwang BF. Fine particulate matter exposure during pregnancy and infancy and incident asthma. J Allergy Clin Immunol. 2019;143:2254-62 e5.

101. Yang SI, Lee SY, Kim HB, Kim HC, Leem JH, Yang HJ, et al. Prenatal particulate matter affects new asthma via airway hyperresponsiveness in schoolchildren. Allergy. 2019;74:675-84.

102. Gehring U, Wijga AH, Hoek G, Bellander T, Berdel D, Bruske I, et al. Exposure to air pollution and development of asthma and rhinoconjunctivitis throughout childhood and adolescence: a population -based birth cohort study. Lancet Respir Med. 2015;3:933-42.

103. Lim H, Kwon HJ, Lim JA, Choi JH, Ha M, Hwang SS, et al. Short-term Effect of Fine Particulate Matter on Children's Hospital Admissions and Emergency Department Visits for Asthma: A Systematic Review and Meta-analysis. J Prev Med Public Health. 2016;49:205-19.

104. Fan J, Li S, Fan C, Bai Z, Yang K. The impact of PM2.5 on asthma emergency department visits: a systematic review and meta-analysis. Environ Sci Pollut Res Int. 2016;23:843-50. 